України ім. Богдана Хмельницького. - Хмельницький, 2015. - 333 с. б. Куртась С. А. Сьогодення магістратури / С. А. Куртась // Український науково-практичний журнал // Магістр медсестринства. - Житомир : Полісся. - 2010. Вип. 1 (4). - С. 24-28. 7. Лукащук I. М. Особливості підготовки майбутніх медичних сестер на основі міжпредметних зв'язків при вивченні хіміко-біологічних дисциплін / I. М. Лукащук // Педагогіка формування творчої особистості у вищій і загальноосвітній школах: [зб. наук. праць] / [редкол.: Т. І. Сущенко (голов.ред.) та ін.]. - Запоріжжя : КПУ, 2015. - Вип. 43 (93). C. 200-208. 8. Лукащук І. М. Теоретичні засади формування фахової компетентності майбутніх медичних сестер у медичному коледжі / I. М. Лукащук // Вісник Національної академії Державної прикордонної служби України. - 2015.- Вип. 1.- Режим доступу : http://nbuv.gov.ua/j-pdf/Vnadps_2015_1_11.pdf 9. Лукащук I. М. Міжпредметні зв’язки у підготовці майбутніх медичних сестер у медичному коледжі / I. М. Лукащук // Науковий вісник Ужгородського національного університету: Серія «Педагогіка. Соціальна робота». 2014. - № 33. -С. 108-111. 10. Махновська I. P. Професійна підготовка магістрів сестринської справи в умовах ступеневої освіти [Рукопис] : дис. на здоб. наук. ступеня канд. пед. наук : 13.00.04 / Махновська Ірина Романівна; М-во освіти і науки України, Житомир. держ. ун-т ім. І. Франка. - Житомир, 2015. - 312 с. 11. Методика формування професійної компетентності медичних сестер у процесі їх практичної підготовки / Інна Губенко, Ірина Радзієвська, Людмила Бразалій. Сайт FAMILY DOCTOR. Режим доступу: http://familydoctor.com.ua/metodika-formuvannya-profesiynoyi-kompetentnosti-medichnih-sester

12. Педагогика: [учеб. пособ. для студентов пед. учебных заведений] / В. А. Сластенин, И. Ф. Исаев, А. И. Мищенко, Е.Н.Шиянов. - [3-є изд.]. - Москва, 2000. - 512 с. 13. Радзісвська I. В. Формування професійної компетентності майбутніх медичних сестер у процесі вивчення фахових дисциплін : автореф. дис. на здобуття наук. ступеня канд. пед. наук / I. В. Радзієвська. - Київ : 2011. - 28 с. 14. Совместная работа на благо здоровья: доклад о состоянии здравоохранения в мире, 2006. - [Электронный ресурс]. - Режим доступа: http://www.who.int/publications/list/whr 2006_overview/ru/ index.html 15. Шарлович 3. П. Формування професійно-педагогічної компетентності медичних сестер сімейної медицини в процесі фахової підготовки : дис. на здобуття наук. ступеня канд. пед. наук : спец. 13.00.04 «Теорія і методика професійної освіти» [Електронний ресурс]/ 3. П. Шарлович ; Житомирський державний університет імені Івана Франка. - Житомир, 2015.- Режим доступу : http://eprints.zu.edu.ua/18684/1/ dys_Sharlovych.pdf

УДК 378.1

Віра Мурашковська

\title{
АНАЛІЗ ПРОБЛЕМИ АДАПТАЦІЇ ПЕРШОКУРСНИКІВ ДО УМОВ НАВЧАННЯ У ВНЗ НА ТЕХНІЧНИХ СПЕЦІАЛЬНОСТЯХ
}

Мурашковська В. П. Аналіз проблеми адаптації першокурсників до умов навчання у ВНЗ на технічних спеціальностях.

У статті розглянуто деякі аспекти адаптації студентів першого курсу до умов навчання у ВНЗ на технічних спеціальностях. Визначено основні труднощі і чинники (як позитивні, так і негативні), які впливають на процес адаптації першокурсників. Адаптація студентів до умов навчання у ВНЗ на технічних спеціальностях являє собою багаторівневий процес, який включає складові елементи соціально-психологічної адаптації та сприяє розвитку інтелектуальних і особистісних можливостей студентів. Необхідно застосовувати нові освітні технології, які орієнтовані на саморозвиток, самовиховання і самореалізацію студентів, які навчаються на технічних спеціальностях.

Ключові слова: адаптація, адаптаційний період, дослідження, навчальна адаптація, першокурсник, проблема, чинники, труднощі адаптації. 
Мурашковская В. П. Анализ проблемы адаптации первокурсников к условиям обучения в вузе на технических специальностях.

В статье рассмотрены некоторые аспекты адаптации студентов первого курса к условиям обучения в вузе на технических специальностях. Определены основные трудности и факторы (как положительные, так и отрицательные), которые влияют на процесс адаптации первокурсников. Адаптация студентов к условиям обучения в вузе на технических специальностях представляет собой многоуровневый процесс, который включает элементы социально-психологической адаптации и способствует развитию интеллектуальных и личностных возможностей студентов. Необходимо применять новые образовательные технологии, ориентированные на саморазвитие, самовоспитание и самореализацию студентов, обучающихся на технических специальностях.

Ключевые слова: адаптация, адаптационный период, исследования, учебная адаптация, первокурсник, проблема, факторы, трудности адатпации.

Muraskovska V. P. Analysis of the problems of adaptation of first-year students to learning environment in high school on the technical specialties.

The article discusses some aspects of adaptation of first-year students to the learning environment in higher education on the technical specialities. The major difficulties and factors (both positive and negative) that influence the adaptation process of first-year students were determined. Adaptation of students to the learning environment in higher education on the technical specialities is a multi-level process that involves an element of social and psychological adaptation and promotes intellectual and personal possibilities of students. It is necessary to apply new educational technologies that focus on self-development, self-fulfillment and students studying in technical specialties.

The proper organization of independent work to expand and deepen knowledge is extremely important to the learning environment in higher education on the technical specialities. Training sessions at the university, including lectures, with respect to the process of learning have only constituent, indicative character. Students must acquire knowledge through active work with textbooks, additional literature, academic and other sources.

During the adaptation process of freshmen to the learning environment in higher education on the technical specialities it is necessaey to take into account the difficulties which is associated with the requirements of the university and the lack of preparedness of first year students. As the students have a new social role, new conditions of life and their ideas about university received before are not dominant, they cosider universities as a training tools for future professional activity.

Important levers of successful adaptation of freshmen are to eliminate the negative factors that affect this process. An active position, joint activity of students and teachers are necessary for successful adaptation. The students should find and choose means and ways to achieve particular educational objectives by themselves and the teachers should create conditions for this. To speed up the adaptation process the impact of all factors simultaneously must be taken into account. Qualitatively new (in general) living standards in higher education can positively affect the entire structure of the student's personality and play a major role in his adaptation to the profession.

Key words: adaptation, an adaptation period, research, training adaptations, freshman, problem, factors, difficulties.

Загальновизнаним є той факт, що освіта надає необхідні знання та вміння, що сприяють формуванню наукового світогляду, розвитку здібностей, адаптації до змін форм діяльності. Тому нині замовлення суспільства - висококваліфікований фахівець, здатний адаптуватися до змін, зумовлених розвитком науки та техніки. Виявлення чинників адаптації до умов навчання у технічному виші студентів першокурсників та аналіз труднощів, які при цьому виникають у навчанні, надасть змогу здійснити перебудову процесу навчання студентів у ВНЗ на технічних спеціальностях відповідно до потреб держави 3 ринковою економікою. 
Питанню адаптації студентів у вищій школі в останнє десятиріччя присвячено чимало наукових праць. Так, зокрема, у дослідженнях Т. Браун, В. Васяновича, О. Галуса, С. Гури, Л. Дябел, Л. Петльованої, Ю. Ткач проаналізовано та узагальнено основні теоретичні підходи до проблеми адаптації в сучасній психолого-педагогічній науці, представлено їх аналіз та визначено сутність поняття адаптація до навчання у ВНЗ. Основні положення i принципи теорії i методики адаптації у процесі навчання розглядаються в роботах В. Беспалько, Н. Кузьміної, В. Монахова, Н. Тализіної та інших. Незважаючи на велику кількість наукових досліджень, присвячених адаптації студентів-першокурсників у ВНЗ, нині недостатньо висвітлена проблема адаптації, яка дозволила б оптимізувати процес адаптації безпосередньо до умов навчання у ВНЗ на технічних спеціальностях.

Метою статmі є аналіз існуючих проблем адаптації до умов навчання у ВН3 на технічних спеціальностях, виявлення основних труднощів та чинників (як негативних, так $\mathrm{i}$ позитивних), які впливають на адаптацію першокурсників у процесі навчання.

Адаптація - одне із ключових понять у науковому дослідженні людської природи. Це природний і необхідний компонент існування людини в системі «організм - навколишнє середовище», в системі «особистість - соціум», тому що механізми адаптації, які мають еволюційне коріння, забезпечують можливість виживання людини.

Використовуваними є різноманітні інтерпретації поняття «адаптація», які мають загальний, широкий зміст, так і такі, що зводяться до одного із можливих процесів адаптації (наприклад, адаптація першокурсників).

У загальних визначеннях адаптації аналізованому поняттю даються різні означення залежно від аспекту розгляду. При цьому під адаптацією, як правило, мають на увазі: процес адаптації організму до навколишнього середовища; відношення гармонії, рівноваги між організмом й навколишнім середовищем; деяка «мета», якої «прагне» організм.

Усі першокурсники, у тій чи іншій формі, проходять адаптацію до нових умов навчання у вищому закладі освіти. Проте цей процес не відбувається автоматично. Особливо виокремлюють останнім часом аспект адаптації людини у швидко мінливих або екстремальних умовах середовища.

Характер і перебіг адаптаційного процесу, що вивчаються педагогікою, позначений складними взаємозв'язками різних об'єктивних та суб'єктивних чинників.

Л. Сгорова виокремлює низку чинників, які, на іiі думку, впливають на процес адаптації, це: соціально-демографічні; психологічні; соціальної зрілості (активність, самостійність та інші); психолого-педагогічні (характер спрямованості, рівень професійної діяльності та інші); педагогічні (логічні зв'язки між дисциплінами навчального процесу) [1].

На думку Ю. Ткач, процес адаптації передбачає передовсім активність самого суб'єкта діяльності, вимагає осмислення своїх дій і вчинків, пошуку власних шляхів рішень відповідно до конкретних умов життєдіяльності, аналіз характерних особливостей i результатів взаємодії (в цьому випадку першокурсника) з новими людьми й обставинами. Адаптація містить у собі складні, багатогранні взаємини людини з довкіллям [4].

А. Сіомічев основними чинниками адаптованості студентів у ВНЗ назвав: інтелектуальність, тривожність, товариськість і соціальну зрілість. Він виокремлює три характерні риси процесу адаптації студентів у ВНЗ: успіх в одному з домінуючих напрямків діяльності не залежить від рівня адаптації в інших напрямках; успіх чи невдача в пізнанні доповнюються відповідно успіхом чи невдачею в спілкуванні; успіх у домінантному напрямку діяльності супроводжується неуспіхом у додатковому напрямку. Дослідник дійшов висновку, що найхарактернішою для студентів $\epsilon$ адаптація переважно в одній сфері діяльності (або в пізнанні, або в спілкуванні) [3]. Це стосується і студентів, які навчаються на технічних спеціальностях.

Аналіз науково-педагогічної літератури і практичного досвіду роботи у ВНЗ показав, що перехід випускника школи в позицію студента пов'язано з низкою труднощів, які можна схарактеризувати як «адаптація першокурсників до навчання у ВНЗ».

Уміння реалізувати себе в багатьох формах діяльності, передбачених у вищому закладі 
освіти, і визначають адаптованість до студентського життя. Умови навчання у виші на технічних спеціальностях висувають підвищені вимоги до адаптивних механізмів студентів. Особливо актуальним стає вміння адаптуватись до умов навчання для представників інженерних спеціальностей, оскільки їх професійна діяльність охоплює не тільки взаємодію людини й техніки, але й діалектичний зв'язок між попередніми й новітніми науково-практичними досягненнями та динамічне інформаційне поле.

Педагогічні дослідження останніх років, присвячені адаптації першокурсників, показують, що труднощі адаптації до умов навчання у ВНЗ на технічних спеціальностях пов'язані не стільки зі слабкою академічною підготовкою, як 3 несформованістю у випускників шкіл таких особистих якостей, як готовність до навчання; вміння навчатися самостійно; контролювати й оцінювати себе; володіти своїми індивідуальними способами пізнавальної діяльності; уміння правильно розподіляти час для самостійної підготовки. У наш час почався процес експоненціального зростання інформації та стрімкий розвиток науково-технічного прогресу, а це потребує докорінної зміни змісту навчання і активного пошуку шляхів підвищення ефективності процесу адаптації.

Адаптація студентів до умов навчання у ВНЗ на технічних спеціальностях $€$ багаторівневим процесом, який включає складові елементи соціально-психологічної адаптації та сприяє розвитку інтелектуальних і особистісних можливостей студентів. У свою чергу, адаптаційний процес пов'язаний із розв'язанням цілої низки різних проблем. Ураховуючи все вище сказане про адаптаційний період першокурсників, ми особливу роль відводимо навчальній адаптації. Проблема навчальної адаптації повинна бути розв'язаною протягом першого, максимум - другого курсу.

Під навчальної адаптацією студентів ми розуміємо частину загальної адаптації, у процесі якої студенти-першокурсники набувають узагальнених навчальних умінь для успішного навчання та прийняття рішення отримати відповідний рівень знань, а також як процес приведення основних параметрів його соціальних і особистісних характеристик у стан динамічної рівноваги з умовами вишівського середовища.

У цьому визначенні ми використовуємо поняття «узагальнені навчальні вміння», яке було введено А. Усовою [5], воно є ключовим у сучасних умовах і акцентує увагу на змістово-операційному аспекті процесу адаптації студентів першого курсу у процесі навчання.

Отже, адаптація студентів першого курсу до умов навчання у ВНЗ на технічних спеціальностях $є$ складним та багатогранним процесом, який пов'язаний із необхідністю подолання низки труднощів, що мають як об'єктивний, так і суб'єктивний характер: труднощі адаптації до нових форм навчання (перехід від шкільної системи навчання до системи, яка передбачає значну частку самостійної роботи); нова система оцінювання знань; прогалини в одержаних у школі знаннях, зокрема не достатній рівень базової шкільної підготовки; нерівномірність навантажень, які періодично значно зростають; значно вища інтенсивність розумової праці в умовах вищого навчального закладу, більший обсяг знань, які необхідно засвоїти; невміння самостійно працювати 3 навчальним матеріалом над поглибленням своїх знань; відсутність навичок вивчення матеріалу з різних підручників, конспектів і методичної літератури, які б повністю відповідали програмі курсу; проблема раціонально організовувати свій час; соціалізація в умовах вишівського середовища.

На наш погляд, перший рік навчання більшою мірою вирішує завдання фундаменталізації основних знань для професійної підготовки в наступні роки студентського життя. Отже, успішне проходження цього етапу адаптації $\epsilon$ важливою передумовою для подальших досягнень студента. Звідси виникає необхідність проаналізувати i виявити чинники, що прискорюють адаптаційний процес саме на першому курсі і допомагають першокурсникам швидше пристосуватися до умов навчання.

Труднощі, які має першокурсник у зв'язку з переходом на нові форми і методи навчальної діяльності, є закономірними. Вступ випускника середньої школи до ВНЗ і подальша його адаптація до нових форм і методів навчання призводять до необхідності 
перебудови процесу набуття нових знань, який складався роками.

Вишівське навчання має суттєві відмінності в порівнянні зі шкільним. Більше того, деякі шкільні стереотипи навчальної діяльності не підходять для вишівського навчання. У школі основна робота із засвоювання нових знань здійснюється на уроці під керівництвом учителя, а домашня робота учня зводиться переважно, до повторення й заучування матеріалу. Це приводить до того, що більшість першокурсників слабко пристосовані до осмислення нового матеріалу. Засвоєння знань у них зводиться до читання матеріалу за конспектом, при цьому студенти намагаються не стільки зрозуміти матеріал, скільки запам'ятати його. Система шкільного навчання побудована так, що вивчення нового матеріалу i його закріплення об’єднуються в єдине ціле структурою уроку. У ВН3 викладання нових знань на лекціях і їх закріплення на практичних заняттях переважно розділені в часі. Тому у ВНЗ робота із засвоювання теоретичного матеріалу, який читається на лекції, повинна збігатися за часом із процесом самостійної позааудиторної роботи й супроводжуватися глибоким осмисленням і самоконтролем. Від того, наскільки правильно організовується ця робота, залежить глибина і міцність знань студентів.

Відсутність наступності у формах і методах навчання при переході від школи до ВН3 створює перешкоди для взаєморозуміння студентів і викладачів, унаслідок чого процес навчання не має продуктивного характеру, який має важливе значення для ефективного засвоєння знань. У психологічному плані це означає, що деякі учні або студенти можуть втрачати віру в себе [2].

Наприкінці кожного семестру настає момент, якого бояться багато студентів екзаменаційна сесія. Перша сесія для студента першокурсника - це практично завжди шок. Хвилювання й переживання студентів цілком виправдані, у разі невдалої здачі сесії студенти позбавляються стипендії і можуть бути відраховані.

Значною мірою якість навчання в сучасних умовах залежить від технології і методів навчання, оскільки численні спроби зберегти традиційне навчання не сприяє досягненню позитивних результатів. Необхідно застосовувати нові освітні технології, які орієнтовані на саморозвиток, самовиховання й самореалізацію студентів, які навчаються на технічних спеціальностях.

Досвід показує, що частина першокурсників не справляється 3 вишівським навчальним навантаженням. Провідними чинниками, які не дозволяють ефективно засвоювати нові дисципліни, є: порушення принципу наступності у викладанні; низький рівень шкільної підготовки і недостатньо сформоване алгоритмічне мислення; принципова відмінність обсягів інформації, які вивчаються в школі і ВН3; несформованість у випускників шкіл навичок самостійного навчання; нездатність справитися 3 тягарем соціальних і психологічних проблем; низька мотивація навчальної діяльності і слабкий самоконтроль і самоорганізованість.

Окрім того, необхідно вказати на важливий психологічний аспект: студенти 3 недостатнім рівнем знань важко адаптуються в колективі і мають негативний статус у групі. Досвід роботи у ВНЗ показує, що студенти молодших курсів не можуть самостійно контролювати хід навчання, систематично працювати протягом семестру. На важливе значення аналізованого процесу адаптації молодших курсів указує, наприклад, Д. Зюзін: «Відомо багато випадків відсіву студентів уже на перших двох курсах у зв'язку 3 перенавантаженням, слабкою підготовленістю до інтенсивної розумової праці...». Особливо це стосується першокурсників, які навчаються на технічних спеціальностях. У всіх ВНЗ спеціально планується система заходів, що сприяє адаптації першокурсників до умов вишу. До числа найбільш важливих заходів відносяться: робота з формування і комплектування академічних груп; посвята у студенти і читання курсу «Вступ до спеціальності».

Надзвичайно важливе значення для адаптації до умов навчання у ВНЗ на технічних спеціальностях має правильна організація самостійної роботи студентів із розширення й поглиблення своїх знань. Навчальні заняття у ВНЗ, у тому числі лекції, мають стосовно процесу засвоєння знань тільки установчий, орієнтовний характер. Студентам необхідно 
самим активно засвоювати знання різними шляхами: працювати з підручниками, додатковою літературою, науковими джерелами. Звичайно, було б неправильно вважати, що першокурсник не зовсім готовий до вишівського навчання. Лекцію не можна розглядати як головне джерело знань, вона лише відіграє роль чинника, який спрямовує самостійну і творчу діяльність студентів. Першокурсника необхідно вчити навчатися - це незаперечна істина.

Як мотивація навчальної діяльності студентів до умов навчання у ВНЗ на технічних спеціальностях і один із провідних чинників їх адаптації у ВНЗ постають вимоги майбутньої роботи за спеціальністю. Якісно новий (в цілому) рівень життя у ВНЗ може позитивно вплинути на всю структуру особистості студента і зіграти головну роль у його адаптації до професії.

Отже, сам по собі тільки процес навчання навіть на найвищому рівні його організації не забезпечує належно адаптацію студентів до умов вищої школи. У зв'язку з цим доречно говорити про сукупність чинників, які позитивно впливають на адаптаційний процес студентів-першокурсників: якісна і чітко продумана організація навчальної діяльності першокурсників; позитивне ставлення до навчання; умотивована навчальна діяльність; формування i застосування творчих здібностей особистості на навчально-практичних заняттях; практичні навики для майбутньої роботи; професійна орієнтація; взаємодія між студентом і викладачем; ефективна діяльність куратора; участь у процесі адаптації першокурсників органів студентського самоврядування; залучення першокурсників до різних видів студентської діяльності (наукова і спортивна робота, художня творчість та ін.).

На нашу думку, усвідомлений процес реалізації отриманих знань означає передовсім засвоєння нових видів навчальної діяльності і засвоєння головного виду діяльностітворчості в системі навчання. За відсутності цих умов це не адаптація, а зовнішнє пристосування, що призводить до комфортної поведінки, але пасивного існування.

У період адаптаційного процесу першокурсників до умов навчання у ВНЗ на технічних спеціальностях, необхідно враховувати труднощі, які у зв'язку з цим виникають і зумовлені невідповідністю, яка пов'язана із вимогами ВНЗ та недостатньою готовністю до них студентів першого курсу. Оскільки у студентів 3'являється нова соціальна роль, нові умови життя і в них поки що не домінують ті уявлення про ВНЗ, які вони одержали раніше, вони розглядають ВНЗ як умову підготовки до майбутньої професійної діяльності.

Важливими важелями успішної адаптації першокурсників $є$ усунення негативних чинників, які впливають на цей процес. Для успішної адаптації необхідним також $є$ вияв активної позиції, яка повинна бути не тільки у викладача, але і у студента, тобто повинна бути спільна діяльність. Студент повинен сам знаходити і вибирати для себе способи і шляхи для досягнення тієї чи тієї навчальної мети, а викладач - створювати для цього умови. Для прискорення адаптаційного процесу необхідно врахувати вплив усіх чинників.

\section{Література}

1. Егорова Л. Г. Факторы адаптации студентов к учебно-воспиталельному процессу технического вуза: автореф. дис. на соискание ученой степени канд. пед. наук / Л. Г. Егорова. - Ленинград, 1978. - 22 с. 2. Мурашковська В. П. Довузівська підготовка у ВН3 - шлях підвищення рівня успішності першокурсників 3 математики / В. П. Мурашковська // Вісник Черкаського університету. Серія: Педагогічні науки. Вип. № 8 (341). - Черкаси, 2015. - 152 с. 3. Сиомичев А. В. Психологические особенности адаптации студентов в сфере познания и общения в вузе : автореф. дис. на соискание ученой степени канд. пед. наук / А. В. Сиомичев. - Ленинград, 1985. - 22 с. 4. Ткач Ю. М. Проблеми адаптації студентів-першокурсників економічних факультетів університетів / Ю. М. Ткач // Міжнародний збірник наукових робіт. - Донецьк : Фірма ТЕАН, 2011. - 132 с. (Міжнародна програма «Евристика та дидактика точних наук»). - С. 39-43. 5. Усова А. В. Формирование учебно-познавательных умений в процессе изучения предметов естественного цикла / А. В. Усова / Физика. Первое сентября. - 2006. - № 16. - С. 3-4. 